\title{
Substrate Construes the Copper and Nickel Ions Impacts on the Mushroom Tyrosinase Activities
}

\author{
N. Gheibi, A. A. Saboury, ${ }^{*}$ and K. Haghbeen ${ }^{\dagger}$ \\ Institute of Biochemistry and Biophysics, University of Tehran, Tehran, Iran.*E-mail: saboury@ut.ac.ir \\ ${ }^{\dagger}$ The National Research Center for Genetic Engineering and Biotechnology, Tehran, Iran \\ Received February 1, 2006
}

\begin{abstract}
Mushroom tyrosinase (MT) structural changes in the presence of $\mathrm{Cu}^{2+}$ and $\mathrm{Ni}^{2+}$ were studied separately. FarUV CD spectra of the incubated MT with the either of the metal ions indicated reduction of the well-ordered secondary structure of the enzyme. Increasing in the maximum fluorescence emission of anilinonaphthalene8-sulfonic acid (ANS) was also revealing partial unfolding caused by the conformational changes in the tertiary structure of MT. Thermodynamic studies on the chemical denaturation of MT by dodecyl trimethylammonium bromide (DTAB) showed decrease in the stability of MT in the presence of $\mathrm{Cu}^{2+}$ or $\mathrm{Ni}^{2+}$ using their activation concentrations. Both activities of MT were also assessed in the presence of different concentrations of these ions, separately, with various monophenols and their corresponding diphenols. Kinetic studies revealed that cresolase activity on $p$-coumaric acid was boosted in the presence of either of the metal ions, but inhibited when phenol, L-tyrosine, or 4-[(4-methylphenyl)azo]-phenol was substrate. Similarly, catecholase activity on caffeic acid was enhanced in the presence of $\mathrm{Cu}^{2+}$ or $\mathrm{Ni}^{2+}$, but inhibited when catechol, L-DOPA, or 4-[(4methylbenzo)azo]-1,2-benzenediol was substrate. Results of this study suggest that both cations make MT more fragile and less active. However, the effect of the substrate structure on the MT allosteric behavior can not be ignored.
\end{abstract}

Key Words : Mushroom tyrosinase, Monophenols, Diphenols, Nickel, Copper

\section{Introduction}

Tyrosinase (EC 1.14.18.1) is a bifunctional enzyme, which catalyzes ortho-hydroxylation of monophenols (cresolase activity) and oxidation of catechols to the corresponding ortho-quinones (catecholase activity). ${ }^{1} o$-Quinones follow some other enzymatic and nonenzymatic reactions, which result in formation of biopolymers like melanin. This macromolecule, the most famous product of tyrosinase, is the natural pigment of mammalian hair, eye, and skin., ${ }^{2,3}$ Undesirable browning of fruits and vegetables during postharvest handling has also been ascribed to tyrosinase. ${ }^{4}$

The interaction of protein with a metal ion is of interest because of various reasons: this includes biochemical standpoint and pathological prospective. Studying the interactions between metal ions and proteins are important especially with respect to their thermodynamic and kinetic stabilities. ${ }^{5,6}$ Moreover, such studies could be informative about the enzymatic activity under conditions of metal ion tolerance and toxicity. ${ }^{7}$

Survey of literatures shows that the impact of metal ions on the melanogensis process have been studied from different but mainly nonenzymatic aspects such as cation exchange properties of melanins, ${ }^{8,9}$ melanin structural modification induced by metal ions, ${ }^{10}$ effect of metal ions on the rearrangement of dopachrome ${ }^{11}$ etc. In contrast, less attention has been paid to the possible interactions of metal ions and tyrosinase. However, a characteristic feature of melanincontaining tissues is their high content of some heavy metals, in particular zinc, copper and iron. ${ }^{12}$ For example, high level of these metal ions have been found in the choroid of eye,$^{13,14}$ black hair, ${ }^{15}$ pigmented moles ${ }^{16}$ and isolated melanosoms from Harding passey, horse and human melanomas. ${ }^{17}$

Similarities between mushroom tyrosinase (MT) and other tyrosinases, specially mammal tyrosinase,${ }^{18,19}$ has made it an apt example for in-vitro studies in this field. So, in pursuit of our works on MT stability ${ }^{20-22}$ and considering the importance of the enzyme-divalent metal ion interactions, ${ }^{23-27}$ this work was devoted to an investigation on the effect of $\mathrm{Cu}^{2+}$ and $\mathrm{Ni}^{2+}$ on the MT structure and activity. In a previous work on Sepia officinalis tyrosinase, it had been reported that $\mathrm{Cu}^{2+}$ inhibited tyrosinase activities while $\mathrm{Ni}^{2+}$ showed no effect. ${ }^{28}$

\section{Materials and Methods}

Materials. Mushroom tyrosinase (MT; EC 1.14.18.1), specific activity 3400 units/mg, was purchased from Sigma. Dihydrocaffeic acid, Caffeic acid (CA), p-coumaric acid (COA), phenol, catechole, L-tyrosine and 3-(3,4-dihydroxyphenyl) alanine (L-DOPA), were taken from authentic samples, and 4-[(4-methylphenyl) azo]-phenol (Me-PAPh) and 4-[(4-methylbenzo) azo]-1,2-benzenediol (MeBACat), were synthesized. ${ }^{29}$ Dodecyl trimethylammonium bromide (DTAB) and anilinonaphthalene-8-sulfonic acid (ANS) were obtained from sigma. Analytical grade of $\mathrm{CuSO}_{4}$ and $\mathrm{Ni}\left(\mathrm{NO}_{3}\right)_{2}$ from Merck were used. The buffer used in the assay was $2.5 \mathrm{mM}$ phosphate buffer solution (PBS), $\mathrm{pH}=$ 6.8 , which its salts were obtained from Merck. All experi- 
ments were carried out in $20^{\circ} \mathrm{C}$ and solutions were prepared in doubly distilled water.

\section{Methods.}

Kinetic Measurements: The kinetic assays of catecholase and cresolase activities were carried out using Cary spectrophotometer, 100 Bio model, with jacketed cell holders. Freshly prepared enzyme and substrate solutions were used in this work. All enzymatic reactions were run in phosphate buffer $(2.5 \mathrm{mM})$ at $\mathrm{pH}=6.8$ in a conventional quartz cell thermostated to maintain the temperature at $20 \pm 0.1{ }^{\circ} \mathrm{C}$. The selected conditions of solvent, buffer, $\mathrm{pH}$, temperature, and enzyme concentration were applied for assaying the oxidase activity of MT according to our previous studies. ${ }^{30,31}$ Cresolase reactions of monophenols were treated by depletion of phenol, Me-PAPh and COA, in their maximum wavelengths of $270 \mathrm{~nm}, 352 \mathrm{~nm}$ and $288 \mathrm{~nm}$, respectively, or increasing in absorbance of DOPA quinone as the product of L-tyrosine in $475 \mathrm{~nm}$. In catecholase reactions depletion of related diphenols substrates catechole, MeBACat and CA and were measured in $275 \mathrm{~nm}, 364 \mathrm{~nm}$ and $311 \mathrm{~nm}$, respectively, and increase in DOPAquinone absorbance in $475 \mathrm{~nm}$ as L-DOPA product. MT activity in the presence dihydrocafeic acid in catecholase reactions assessed with increased of its product in $400 \mathrm{~nm}$. Substrate addition followed after incubation of the enzyme with different concentrations of $\mathrm{Cu}^{2+}$ and $\mathrm{Ni}^{2+}$. Cresolase reactions were followed for $10 \mathrm{~min}$ using an enzyme concentration of $70.8 \mu \mathrm{M}, 240 \mathrm{unit} / \mathrm{mL}$ and in catecholase reactions for 2 min using an enzyme concentration of $11.8 \mu \mathrm{M}, 40$ unit $/ \mathrm{mL}$. For $\mathrm{pH}$ studies, we used acetate buffer $(100 \mathrm{mM})$ in the $\mathrm{pH}$ range of $4-5$, and PBS $(2.5 \mathrm{mM})$ in the $\mathrm{pH}$ range of 6-8. Kinetic measurements of catecholase reaction with $\mathrm{CA}$ in different $\mathrm{pHs}$ were carried out in the absence or in the presence of $\mathrm{Cu}^{2+}$ and $\mathrm{Ni}^{2+}(1$ $\mathrm{mM})$. All assays were repeated at least three times. Definitions of units were defined by the vender. Accordingly, one unit cresolase activity is equal to the 0.001 change in the optical density of L-tyrosine per minute at $280 \mathrm{~nm}$ in $3 \mathrm{~mL}$ of the reaction mixture at $25^{\circ} \mathrm{C}$ and $\mathrm{pH}=6.5$. Similarly, one unit of catecholase activity is equal to the 0.001 change in the optical density of ascorbic acid per minute at $265 \mathrm{~nm}$ in 3 $\mathrm{ml}$ of the reaction mixture $\left(25{ }^{\circ} \mathrm{C}\right.$ and $\left.\mathrm{pH}=6.5\right)$, when catechol or L-DOPA is used as substrate.

Long-term Inactivation of MT: Inactivation experiments were carried out by UV spectrophotometry through catecholase reaction in $4{ }^{\circ} \mathrm{C}$ plus or minus of activatory concentrations of $\mathrm{Ni}^{2+}$ and $\mathrm{Cu}^{2+}$. Aliquots containing 11.8 $\mu \mathrm{M}$ (40 unit $/ \mathrm{mL}$ ) enzyme were removed at various times and assayed for enzyme activity after addition of CA, as a substrate.

Protein Stability Measurements: To obtain the effect of these metal ions on the thermodynamical stability of the enzyme, chemical denaturation profiles of MT were recorded by titration of a protein solution $0.12 \mathrm{mg} / \mathrm{mL}$ with aliquots from a $50 \mathrm{mM}$ stock solution of DTAB, as a cationic surfactant. Conformational change of the protein was obtained at wavelength of $280 \mathrm{~nm}$ by the spectrophotometric technique. Thermal denaturation curves of MT $(0.21 \mathrm{mg} /$
$\mathrm{mL}$ ) by CD technique following the ellipticity in $222 \mathrm{~nm}$ were investigated. The curves were obtained with and without the presence of $\mathrm{Cu}^{2+}$ and $\mathrm{Ni}^{2+}$ in their activatory concentrations $(1 \mathrm{mM})$, This is a proper concentration that doesn't show any technical limitation.

Circular Dichroism Spectroscopy: The far UV region (190-260) that corresponds to peptide bond absorption was analyzed by an Aviv model 215 Spectropolarimeter (Lakewood, USA) to give the content of regularly secondary structure in MT. For far UV spectra, MT was studied at concentration of $0.21 \mathrm{mg} / \mathrm{mL}$ with $1 \mathrm{~mm}$ path length quartz cell. Protein solutions were prepared in the $2.5 \mathrm{mM}$ PBS buffer at $\mathrm{pH}$ 6.8. The protein solutions were also incubated with $\mathrm{Cu}^{2+}(1 \mathrm{mM})$ and $\mathrm{Ni}^{2+}(1 \mathrm{mM})$ for at least 5 min to obtain the spectra of copper and nickel incubated MT. All spectra were collected in a triplicate from 190 to $260 \mathrm{~nm}$ and a back ground-corrected against buffer blank. The data were smoothed by applying the software, including the fast Fourier-transform noise reduction routine, which allows the enhancement of most noisy spectra without distorting their peak shapes. The results were expressed as ellipticity [deg $\left.\mathrm{cm}^{2} \mathrm{dmol}^{-1}\right)$ ] based on a mean amino acid residue weight (MRW) of 125 for MT having the average molecular weight of $120 \mathrm{kD} .{ }^{32}$ The molar ellipticity was determined as $[\theta]=$ $\left(100 \times(\mathrm{MRW}) \times \theta_{\mathrm{obs}} / \mathrm{cl}\right)$, where $\theta_{\mathrm{obs}}$ is the observed ellipticity in degrees at a given wavelength, $\mathrm{c}$ is the protein concentration in $\mathrm{mg} / \mathrm{ml}$ and $\mathrm{l}$ is the length of the light path in $\mathrm{cm}$. All measurements were carried out at $25{ }^{\circ} \mathrm{C}$ with the help of a thermostatically controlled cell holder attached to a Neslab's RTE-110 circulating water bath with an accuracy of $\pm 0.1^{\circ} \mathrm{C}$. Thermal denaturation of MT $(0.21 \mathrm{mg} / \mathrm{mL})$ carried out by following the ellipticity in $222 \mathrm{~nm}$, using Aviv model 215 Spectropolarimeter.

Fluorescence Measurements: A stock solution of $10 \mathrm{mM}$ ANS was prepared in distilled, deionized water. The concentration of the dye was determined by its absorbance in $350 \mathrm{~nm}$. All experiments were carried out at $25 \mu \mathrm{M}$ ANS. Fluorescence measurements were performed on a Hitachi spectrofluorometer, model MPF-4 (Japan), $150 \mathrm{~W}$ xenon lamp, equipped with a data recorder, DR-3 and excitation and emission slits were set at 10 and $10 \mathrm{~nm}$, respectively. Emission spectra were recorded from 400 to $650 \mathrm{~nm}$ with excitation at $380 \mathrm{~nm}$ in increments of $1 \mathrm{~nm}$ and ANS fluorescence of native MT, $\mathrm{Cu}^{2+}$ and $\mathrm{Ni}^{2+}$-MT complexes were measured by exciting the protein solution $(0.17 \mathrm{mg} /$ $\mathrm{mL}$ ) in $2.5 \mathrm{mM}$ PBS buffer at $\mathrm{pH} 6.8$ and $25^{\circ} \mathrm{C}$, in $1-\mathrm{mL}$ semi-micro quartz cuvettes with a $1-\mathrm{cm}$ excitation light path. In these experiments for structural analysis of MT and comparison with $\mathrm{CD}$ data same activatory concentrations (1 $\mathrm{mM}$ ) of $\mathrm{Cu}^{2+}$ and $\mathrm{Ni}^{2+}$ have been used.

\section{Results and Discussion}

Reduction in the negative ellipticity observed in the Far UV-CD spectra, Figure 1, reveal some changes in the secondary structure of MT after incubation with the either of the metal ions. However, stronger effect of copper ion is 


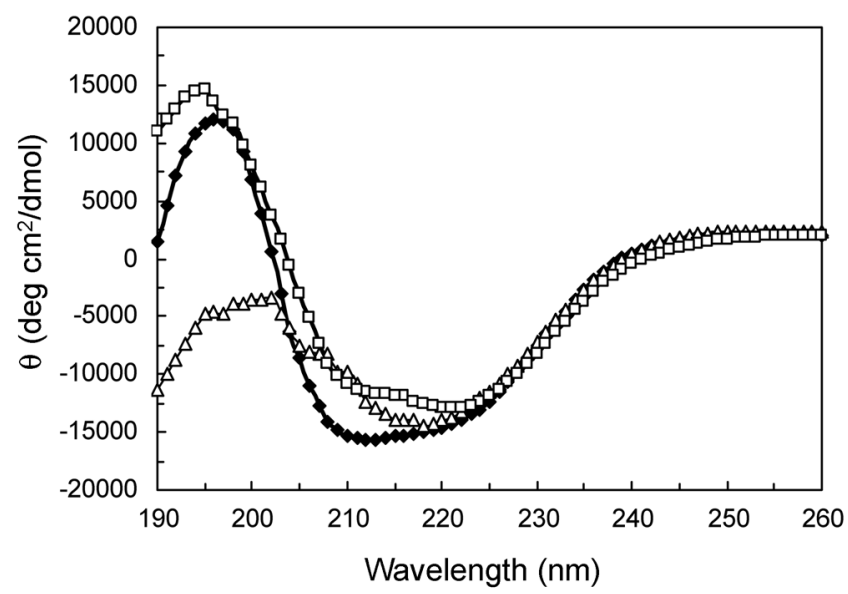

Figure 1. Far-UV CD spectra as ellipticity $[\theta]$ of the $0.21 \mathrm{mg} / \mathrm{mL}$ MT in $2.5 \mathrm{mM}$ PBS, $25^{\circ} \mathrm{C}$ and $\mathrm{pH} 6.8$ in the absence $(\bullet)$ and presence of $1 \mathrm{mM} \mathrm{Cu}^{2+}(\triangle)$; and $\mathrm{Ni}^{2+}(\square)$.

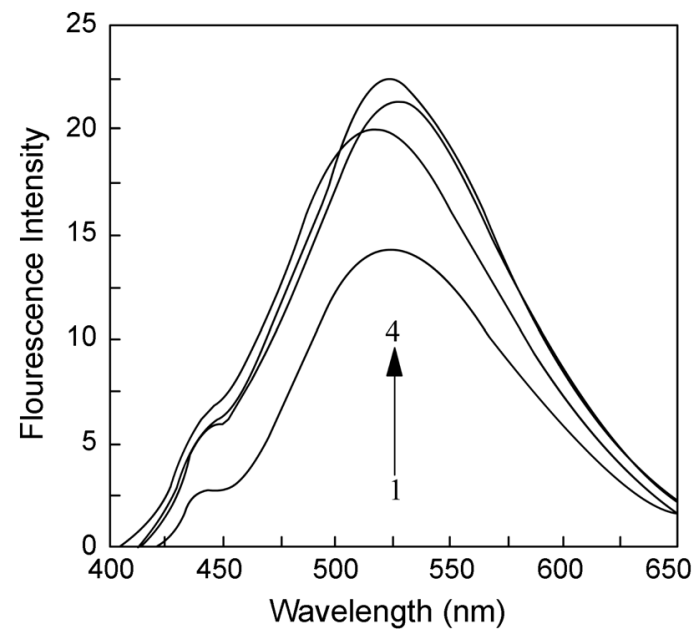

Figure 2. ANS fluorescence emission spectra of the $0.17 \mathrm{mg} / \mathrm{mL}$ MT in $2.5 \mathrm{mM}$ PBS, $25^{\circ} \mathrm{C}$ and $\mathrm{pH}$ 6.8. Only ANS (1); ANS+MT (2); ANS $+\mathrm{MT}+\mathrm{Ni}^{2+}$ (3) and ANS $+\mathrm{MT}+\mathrm{Cu}^{2+}$ (4) The excitation wavelength was $380 \mathrm{~nm}$.

apparent. Analysis of these spectra indicate that the $\beta$-sheet construction of the native enzyme has been remained almost intact in the presence of either of the ions, but the share of the $\alpha$-helix construction which comprises $36 \%$ of the native enzyme structure has been reduced to $33 \%$ and $24 \%$ in the presence of $1 \mathrm{mM}$ of $\mathrm{Ni}^{2+}$ or $\mathrm{Cu}^{2+}$, respectively. Simultaneously, the share of coil construction has been increased from $36 \%$ to $50 \%$ and $55 \%$ in the presence of $\mathrm{Ni}^{2+}$ or $\mathrm{Cu}^{2+}$, respectively. ${ }^{33}$

Tertiary structure of enzyme was assessed through ANS fluorescence. The curves in Figure 2 show increasing in the emission intensities after ANS addition to the solutions containing the incubated MT with metal ions. This increasing shows a partial unfolding in tertiary structure of the enzyme.

To evaluate the effect of $\mathrm{Cu}^{2+}$ and $\mathrm{Ni}^{2+}$ on the MT stability, chemical denaturation of the enzyme was investigated by DTAB. The sigmoid denaturation profiles of MT in the
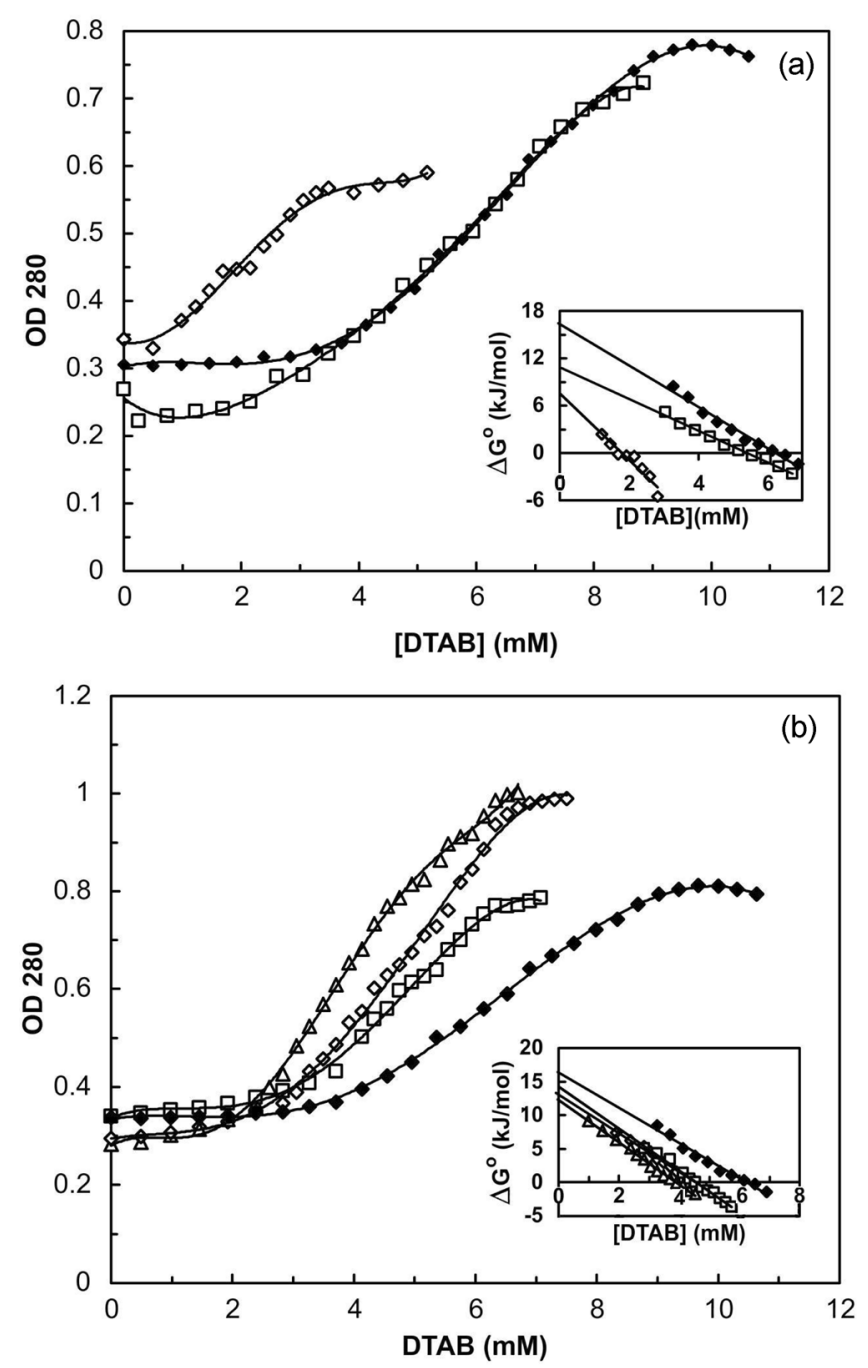

Figure 3. Spectrophotometric titration of $0.12 \mathrm{mg} / \mathrm{mL}$ MT by DTAB solution at $280 \mathrm{~nm}$ in $2.5 \mathrm{mM}$ PBS, $20^{\circ} \mathrm{C}$ and $\mathrm{pH} 6.8$, in the absence $(\diamond)$ and presence of $0.1 \mathrm{mM}(\square) ; 0.5 \mathrm{mM}(\diamond)$ and 1 $\mathrm{mM}(\triangle)$ of $\mathrm{Cu}^{2+}(\mathrm{a})$; and $\mathrm{Ni}^{2+}$ (b). Insets: Linear extrapolation method for calculation of free energy and half denaturant concentration changes in protein denaturation process.

absence and presence of $\mathrm{Cu}^{2+}$ and $\mathrm{Ni}^{2+}$ are shown in Figures $3 \mathrm{a}$ and $3 \mathrm{~b}$, respectively. The obtained graphs were analyzed by considering a two-state mechanism. The Pace theory was used in order to find the transition concentration $[\mathrm{DTAB}]_{1 / 2}$ and the free energy changes for the conformational changes $\left(\Delta G^{\circ}{ }_{\mathrm{H} 2 \mathrm{O}}\right)$ as a reliable thermodynamic parameter indicating the chemical stability of the protein. ${ }^{34-37}$ Assuming the twostate model as follows:

$$
\Delta G^{\circ}{ }_{\mathrm{D}}=-\mathrm{RT} \ln \mathrm{K}_{\mathrm{D}}=-\mathrm{RT} \ln \left(\mathrm{A}_{\mathrm{N}}-\mathrm{A}_{\mathrm{obs}} / \mathrm{A}_{\mathrm{obs}}-\mathrm{A}_{\mathrm{D}}\right)
$$

$R$ is the universal gas constant. $A_{N}$ and $A_{D}$ are the absorbances of the native and denatured species, respectively. $\mathrm{K}_{\mathrm{D}}$ and $\Delta G^{\circ}$ are the equilibrium constant and free energy changes of the denaturation and $\mathrm{A}_{\mathrm{obs}}$ indicates the absorbance observed during titration. According to the Pace or linear extrapolation method, one can write: 
Table 1. Thermodynamic parameters from chemical and thermal denaturation of MT

\begin{tabular}{|c|c|c|c|c|c|c|c|c|}
\hline & \multicolumn{4}{|c|}{ Chemical denaturation } & \multicolumn{4}{|c|}{ Thermal denaturation } \\
\hline & \multicolumn{2}{|c|}{$\begin{array}{c}{[\mathrm{DTAB}]_{1 / 2}} \\
(\mathrm{mM})\end{array}$} & \multicolumn{2}{|c|}{$\begin{array}{l}\Delta \mathrm{G}_{(\mathrm{H} 2 \mathrm{O})} \\
(\mathrm{kJ} / \mathrm{mol})\end{array}$} & \multicolumn{2}{|c|}{$\begin{array}{c}\mathrm{T}_{\mathrm{m}} \\
\left({ }^{\circ} \mathrm{C}\right)\end{array}$} & \multicolumn{2}{|c|}{$\begin{array}{c}\Delta \mathrm{G}^{\mathrm{o}}{ }_{25^{\circ} \mathrm{C}} \\
(\mathrm{kJ} / \mathrm{mol})\end{array}$} \\
\hline & $\mathrm{Cu}^{2+}$ & $\mathrm{Ni}^{2+}$ & $\mathrm{Cu}^{2+}$ & $\mathrm{Ni}^{2+}$ & $\mathrm{Cu}^{2+}$ & $\mathrm{Ni}^{2+}$ & $\mathrm{Cu}^{2+}$ & $\mathrm{Ni}^{2+}$ \\
\hline $0 \mathrm{mM}$ & 6.2 & 6.2 & 16.4 & 16.4 & 50 & 50 & 10.8 & 10.8 \\
\hline $0.1 \mathrm{mM}$ & 5.4 & 4.6 & 10.8 & 14.3 & - & - & - & - \\
\hline $0.5 \mathrm{mM}$ & 1.8 & 4.5 & 7.6 & 13.1 & - & - & - & - \\
\hline $1 \mathrm{mM}$ & - & 3.9 & - & 12.2 & 47.6 & 44.9 & 9.13 & 9.15 \\
\hline
\end{tabular}

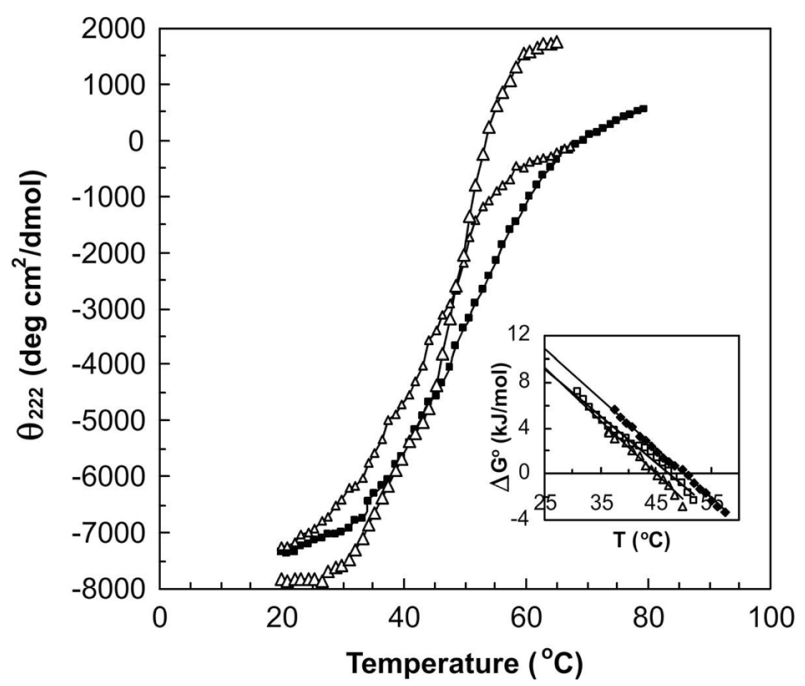

Figure 4. Thermal denaturation curve obtained from molar ellipticity [ $\theta]$ at $222 \mathrm{~nm}$ with $0.21 \mathrm{mg} / \mathrm{mL}$ MT in $2.5 \mathrm{mM}$ PBS, 25 ${ }^{\circ} \mathrm{C}$ and $\mathrm{pH} 6.8$, in the absence $(\diamond)$ and presence $1 \mathrm{mM}$ of $\mathrm{Cu}^{2+}$ $(\diamond)$; and $\mathrm{Ni}^{2+}(\triangle)$. Inset: Linear extrapolation method for calculation of free energy and $\mathrm{T}_{\mathrm{m}}$ changes in before condition.

$$
\Delta G^{\circ}{ }_{\mathrm{D}}=\Delta G^{\circ}{ }_{\mathrm{H} 2 \mathrm{O}}-\mathrm{m} \text { [denaturant] }
$$

$\Delta G^{\circ}{ }_{\mathrm{H} 2 \mathrm{O}}$ is the free energy of conformational stability in the absence of denaturant and $\mathrm{m}$ is a measure of $\Delta G^{\circ}{ }_{\mathrm{D}}$ dependence on the denaturant concentration. Summary of this analysis, determined from the replots outlined in the insets of Figure $3 \mathrm{a}$ and $3 \mathrm{~b}$, is collected in Table 1.

Thermal denaturation of MT in the absence and presence of $\mathrm{Cu}^{2+}$ and $\mathrm{Ni}^{2+}$ was also studied using $\mathrm{CD}$ technique and the above mentioned theory. Results of these experiments, CD spectra of the native and incubated enzyme and the ensuing thermodynamic data are shown in Figure 4 and Table 1, correspondingly. Considering the magnitudes of free energy of both chemical and thermal denaturation experiments indicate decrease in the stability of the protein in the presence of different concentrations of the applied metal ions. Here, again, copper ion seems to be more effective than $\mathrm{Ni}^{2+}$ on the stability of MT. However, the melting point $\left(\mathrm{T}_{\mathrm{m}}\right)$ of the enzyme has been more reduced in the presence of nickel ion.

To see how the structural changes caused by $\mathrm{Cu}^{2+}$ and $\mathrm{Ni}^{2+}$ affect catalytic activities of MT, both activities of the
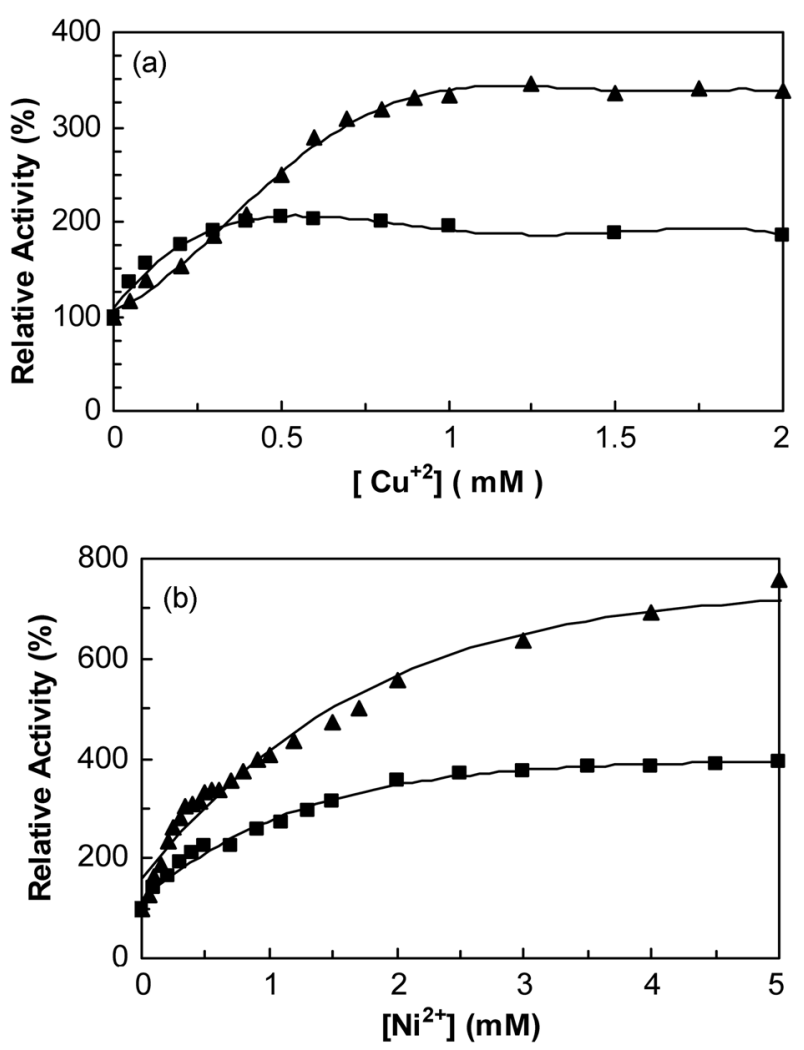

Figure 5. MT activation in the cresolase and catecholase reactions with COA ( $\square$ ) and CA ( $\Delta$ ) in $2.5 \mathrm{mM} \mathrm{PBS}, 20^{\circ} \mathrm{C}$ and pH 6.8, in the presence of $\mathrm{Cu}^{2+}$ (a) and $\mathrm{Ni}^{2+}$ (b).

enzyme were assessed in the presence of these cations. Depend on the applied substrate in the experiment; the collected results can be divided into two distinct groups. As illustrated in Figure 5a and 5b both MT activities have been modified in the presence of COA and its dihydroxy counterpart, $\mathrm{CA}$, in a hyperbolic manner by $\mathrm{Cu}^{2+}$ and $\mathrm{Ni}^{2+}$. Studying catecholase activity of MT on CA in the absence and presence of $\mathrm{Cu}^{2+}$ and $\mathrm{Ni}^{2+}$ at different $\mathrm{pH}(\mathrm{s})$ made known that the activation was more pronounced at the

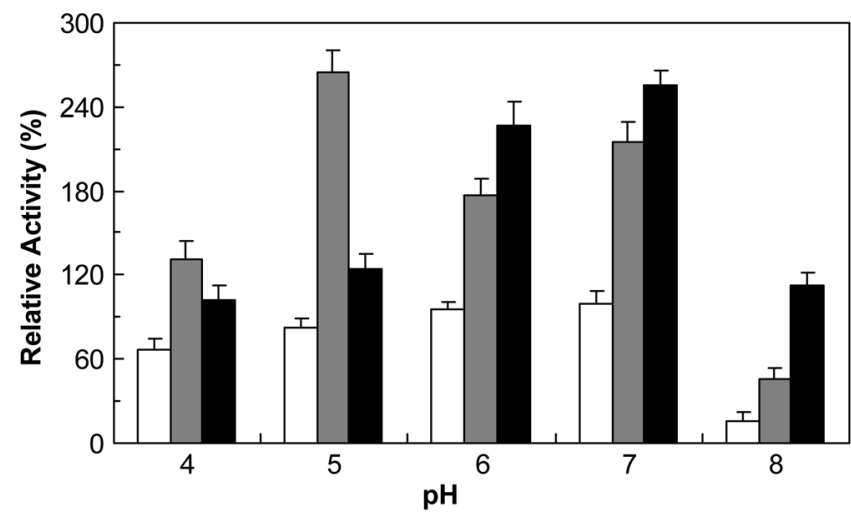

Figure 6. Relative activity of MT in catecholase reactions through CA depletion in different $\mathrm{pH}$ in $2.5 \mathrm{mM}$ PBS for $\mathrm{pH} 6,7,8$ and 100 $\mathrm{mM}$ acetate buffer for $\mathrm{pH} 4,5$; in $20^{\circ} \mathrm{C}$, in the absence (white columns), and presence of $1 \mathrm{mM} \mathrm{Cu}{ }^{2+}$ (gray columns) and $\mathrm{Ni}^{2+}$ (black columns). 


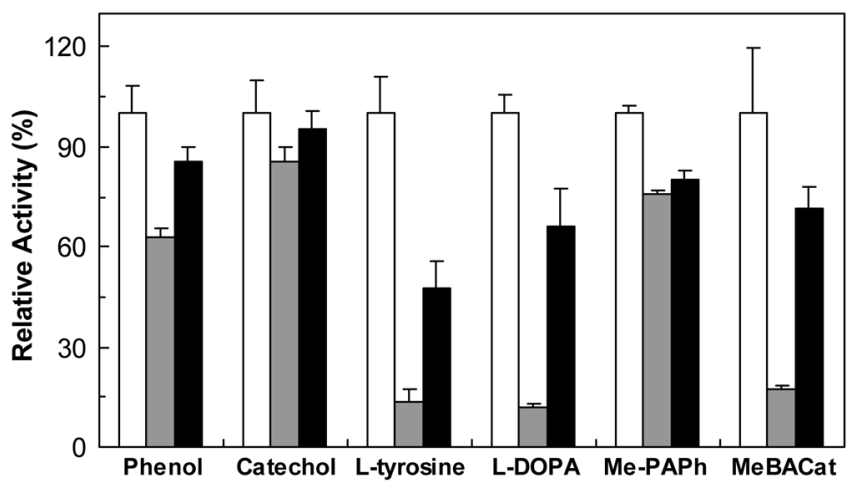

Figure 7. Relative activity of MT through cresolase and catecholase reactions with different monophenol and diphenol substrates in $2.5 \mathrm{mM}$ PBS, $20^{\circ} \mathrm{C}$ and $\mathrm{pH}$ 6.8, in the absence (white column), and presence of $1 \mathrm{mM} \mathrm{Cu}^{2+}$ (gray column) and $\mathrm{Ni}^{2+}$ (black column).

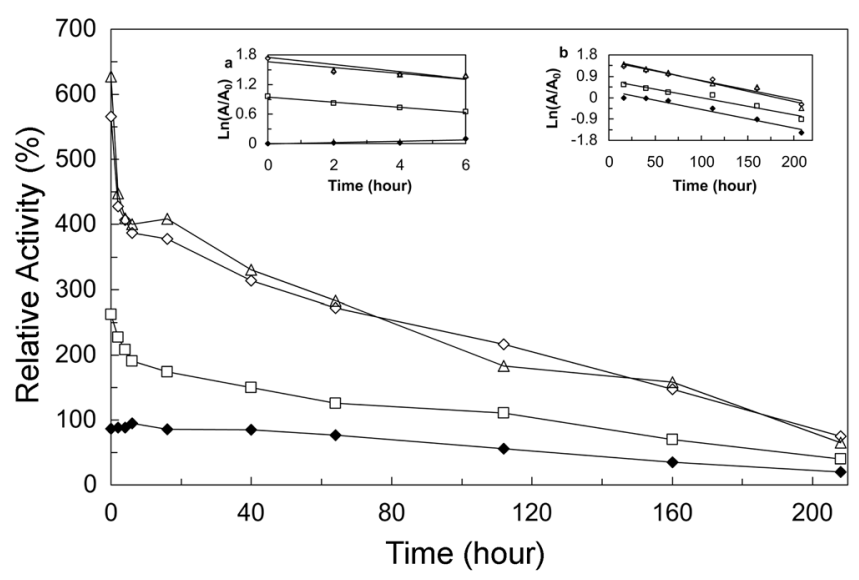

Figure 8. Long-term inactivation of MT in $2.5 \mathrm{mM}$ PBS, $4{ }^{\circ} \mathrm{C}$ and $\mathrm{pH} 6.8$, in the absence $(\diamond)$ and presence of $0.1(\square), 0.5(\diamond)$ and $1 \mathrm{mM}(\triangle)$ of $\mathrm{Cu}^{2+}$. Insets: Rate constants of inactivation $\mathrm{k}_{\text {inact }}$ were obtained from a linear fit according to first-order equation of long-term inactivation, first rapid shorter phase (a), and second prolonged slow phase (b).

optimum $\mathrm{pH}$ for the enzyme activity, Figure 6.

In contrast to what is shown in Figure $5 \mathrm{a}$, Figure 7 discloses that cresolase activity of MT on L-tyrosine, phenol and Me-PAPh has been suppressed and in a similar way catecholase activity on L-DOPA, catechol and MeBACat has also been reduced by both $\mathrm{Cu}^{2+}$ and $\mathrm{Ni}^{2+}$.

Kinetic assays of residual activity of the enzyme through long-term inactivation have been showed in Figure 8 and 9 for $\mathrm{Cu}^{2+}$ and $\mathrm{Ni}^{2+}$, respectively. To evaluate the metal effect on the long-term functional stability of $\mathrm{MT}, \ln \mathrm{A}_{t} / \mathrm{A}_{0}$ was plotted $v s$ time, where $\mathrm{A}_{\mathrm{t}}$ is the activity at time $\mathrm{t}$ after incubation at $4{ }^{\circ} \mathrm{C}$ and $\mathrm{A}_{0}$ is the activity before incubation. The observed rate constants of inactivation, $\mathrm{k}_{\text {inact, }}$ were obtained from a linear fit according to the first-order equation:

$$
\ln \mathrm{A}_{\mathrm{t}} / \mathrm{A}_{0}=-\mathrm{k}_{\text {inact. }} \cdot \mathrm{t}
$$

The long-term inactivation of enzyme shows biphasic pattern, including an initial rapid short phase that follow with a prolonged slow phase. Percent of residual activity in

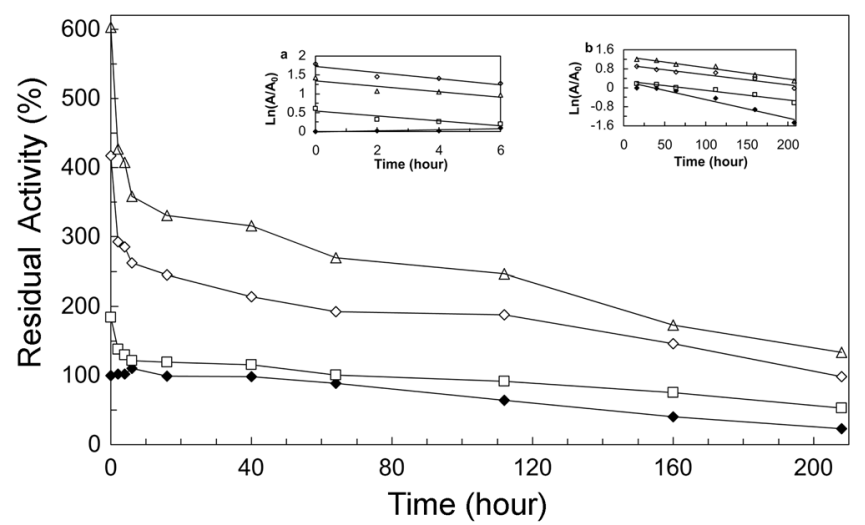

Figure 9. Long-therm inactivation of MT in $2.5 \mathrm{mM}$ PBS, $4{ }^{\circ} \mathrm{C}$ and $\mathrm{pH} 6.8$, in the absence $(\diamond)$ and presence of $0.1(\square), 0.5(\diamond)$ and $1 \mathrm{mM}(\triangle)$ of $\mathrm{Ni}^{2+}$. Insets: Rate constants of inactivation $\mathrm{k}_{\text {inact }}$ were obtained from a linear fit according to first-order equation of longterm inactivation, first rapid shorter phase (a), and second prolonged slow phase (b).

Table 2. Long term stability of MT in the absence and presence of metal ions

\begin{tabular}{|c|c|c|c|c|c|c|c|c|}
\hline & \multicolumn{4}{|c|}{ Residual activity (\%) } & \multicolumn{4}{|c|}{$\mathrm{k}_{\text {inact }} \times 10^{-6} /\left(\mathrm{s}^{-1}\right)$} \\
\hline & \multicolumn{2}{|c|}{$\mathrm{Cu}^{2+}$} & \multicolumn{2}{|c|}{$\mathrm{Ni}^{2+}$} & \multicolumn{2}{|c|}{$\mathrm{Cu}^{2+}$} & \multicolumn{2}{|c|}{$\mathrm{Ni}^{2+}$} \\
\hline & I & $\mathrm{F}$ & I & $\mathrm{F}$ & I & $\mathrm{F}$ & I & $\mathrm{F}$ \\
\hline $0 \mathrm{mM}$ & 100 & 23.2 & 100 & 23.2 & 0 & 2.1 & 0 & 2.17 \\
\hline $0.1 \mathrm{mM}$ & 72.8 & 23 & 65.8 & 44.3 & 14 & 2 & 18 & 1.14 \\
\hline $0.5 \mathrm{mM}$ & 68.4 & 20 & 62.7 & 40 & 16 & 2.2 & 20 & 1.17 \\
\hline $1 \mathrm{mM}$ & 63.7 & 15.8 & 59.4 & 40.3 & 20 & 2.4 & 22 & 1.33 \\
\hline
\end{tabular}

$\mathrm{k}_{\text {inact }}$ : inactivation coefficient; I: initial rapid phase; $\mathrm{F}$ : final prolonged phase

each phase calculate from relation of final enzyme activity to its initial activity. Magnitudes of the residual activity and $\mathrm{k}_{\text {inact }}$ in the absence and presence of different concentrations of metal ions is summarized in Table 2. It is understood from this data that enzyme-metal complex is more fragile than the free enzyme in the first rapid phase, in contrast to the second prolonged slow phase of inactivation.

Palumbo et al. had studied the effect of some divalent metal ions on the kinetic of Sepia officinalis tyrosinase activities. ${ }^{28}$ They reported that $\mathrm{Fe}^{2+}$ activated but $\mathrm{Cu}^{2+}$ and $\mathrm{Mn}^{2+}$ inhibited the activities of the enzyme. They also observed no change in the tyrosinase activity in the presence of $\mathrm{Ni}^{2+}, \mathrm{Zn}^{2+}, \mathrm{Co}^{2+}$, or $\mathrm{Cd}^{2+}$. Although they offered no explanation for the inhibitory effect of $\mathrm{Cu}^{2+}$ and $\mathrm{Mn}^{2+}$ on the tyrosinase activity; they reasoned the observed activity increase in the presence of $\mathrm{Fe}^{2+}$ by considering the reducing ability of that ion. Increase of DOPA-oxidase activity of tyrosinase extracted from liver pigment cells of Rana Esculenta $L$. in a concentration dependent manner in the presence of copper has also been reported and ascribed to the transfer of the copper ions to the apoenzyme. ${ }^{38}$

In a different work on metapotyrosinase, Strothkamp et al. clearly reported that in spite of some weak binding sites on MT for $\mathrm{Co}^{2+}$ or $\mathrm{Zn}^{2+}$; there was no effect on the catalytic activities of the native or reconstituted enzyme by these 
ions. ${ }^{39}$ To shed more light into the interaction of MT and divalent metal ions, the impact of $\mathrm{Ni}^{2+}$ and $\mathrm{Cu}^{2+}$ on the MT structure was first investigated by spectroscopic methods.

When intrinsic fluorescence is impractical like this case, changes in ANS fluorescence could be used to detect non-native partially folded conformations of globular proteins. ${ }^{40-42}$ This is because such intermediates are characterized by the presence of the solvent-exposed hydrophobic clusters to which ANS binds, resulting in a considerable increase in the ANS fluorescence intensity and a blue shift of its maximum emission. ${ }^{43}$

ANS fluorescence spectroscopy results indicate similar changes have been happened in the tertiary structure of MT by $\mathrm{Cu}^{2+}$ and $\mathrm{Ni}^{2+}$, but $\mathrm{Cu}^{2+}$ shows more impact respect to $\mathrm{Ni}^{2+}$. This could be mainly because of different binding ability of these cations.

Details of the tertiary and secondary structure changes were similar. To this point, spectroscopic and thermodynamic results reveal that both $\mathrm{Cu}^{2+}$ and $\mathrm{Ni}^{2+}$ bring about structural changes in the MT which could be referred to a partial unfolding coincide with less thermodynamic stability of MT.

Kinetic studies showed that both copper and nickel followed the same suit in the catalytic activities of MT. Where the nickel ion had boosted MT activity, the copper ion had also similar effect but at various extent. So, why different results are observed, metal activation in Figure 5a and $5 \mathrm{~b}$ in one hand and their inhibition effect in Figure 7 in another hand?

There are two important standpoints for reasoning the experienced differences. In view of the observed changes in the structure and stability of MT in the presence of the studied ions, the results in Figure 7 are not unexpected. Copper ion had brought MT more structural changes and larger instability. It has also made the enzyme less active. But is that really the structural change which makes MT less active?

From a chemical point of view, it is expected that divalent metal ions, more or less, get in the way of the interaction between the substrate and the MT active site via a coordination binding. If it was the case, the catecholase activity of MT on catechol, which is a bidentate ligand and carries no other substitute on its phenolic ring, had to be inhibited more strongly than its phenolic counterpart by the cations. This is not seen in Figure 7. Therefore, it seems more sensible to explain the observed descended activities in Figure 7 in terms of reduction instead of inhibition. In other words, the interactions of the metal ions with MT have caused some conformational changes which have made the enzyme more fragile and less active. So how can we explain the observed activation in Figure 5a and 5b.

All possibilities that may be occurred to $\mathrm{CA}$ and $\mathrm{COA}$ uptake from the cell environment were investigated. The important one is oxidation or complexes of substrates with metals ions; however, time incubation of CA and COA with ions for at least 1 hour didn't show any change in their spectrums. These spectrums gradually showed a decrease

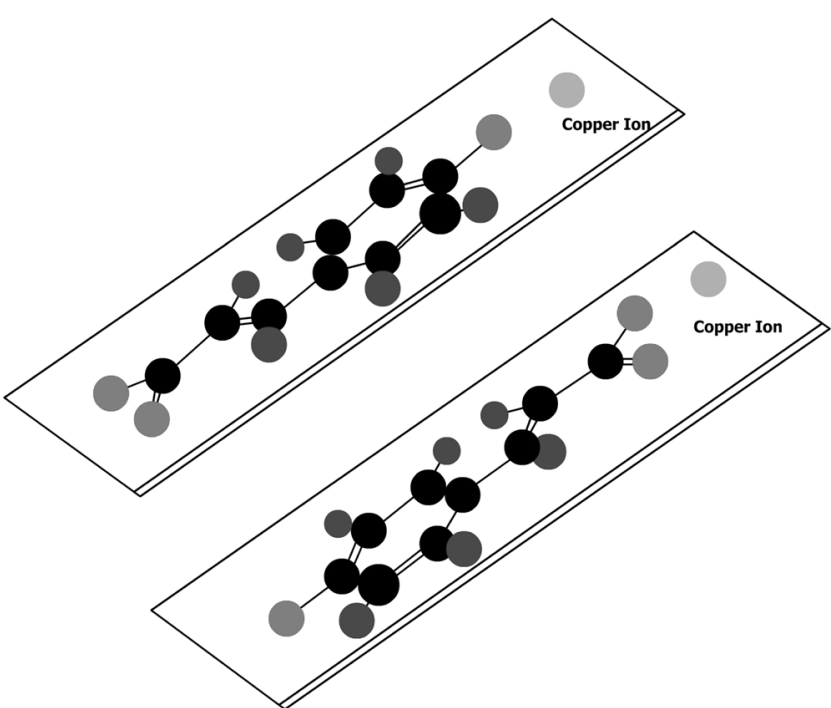

Figure 10. Diagram of copper interaction with COA substrate, interaction of hydroxyl group moiety (up) and carboxylic moiety (low).

after addition of enzyme aliquots. Then, MT activation is induced in the presence of metal ions and CA or COA in comparison of other mono- or diphenol substrates. Survey of literatures refers to the binding of carboxylic moieties in CA and COA to copper. ${ }^{44-46}$ Besides the experiments with dihydrocaffeic acid as a substrate in the presence of the ions didn't show any change in enzyme activity. In this time the best proposal for this activation bears from considering of carboxylic moieties of these substrates.Unlike the molecules cited in Figure 7, COA and its corresponding dihydroxy derivative have free carboxylic terminal attached to $\mathrm{SP}^{2}$ carbon. Thus, the carboxylic residue on COA and CA can be located on the same plane of the phenolic terminal and compete for the coppers in the active site of the enzyme (Fig. 10). Considering the possible interaction of the metal ions with the carboxylic moiety of $\mathrm{COA}$ and $\mathrm{CA}^{44-46}$ the observed activation in Figure 5a and $5 \mathrm{~b}$ can be explained as follow. When MT reacts with COA or CA, these substrates can occupy the active site either by their phenolic or carboxylic terminal, Figure 10. In the presence of the metal cations, the carboxylic moiety binds to the cation and can not compete with the phenolic head for the active site. As a result, the enzymatic reactions go faster.

Although this explanation seems to be in agreement with the literature of MT inhibition ${ }^{44,45}$ as well as the chemistry of $\mathrm{COA}$ and $\mathrm{CA} ;{ }^{4547}$ it does not rule out the possible allosteric interaction between substrate and MT. In fact, the magnitude of the activation shown in Figure 5a and 5b could narrowly be fitted in the above mentioned explanation especially if we accept that $\mathrm{Cu}^{2+}$ and $\mathrm{Ni}^{2+}$ make MT more fragile and less active.

Overall conclusion from kinetic of inactivation, free energy in thermodynamic experiments, and structural analysis of MT in the absence and presence of the ions show more fluctuations of enzyme from $\mathrm{Cu}^{2+}$ in comparison with same concentration of $\mathrm{Ni}^{2+}$. It is also noteworthy to remind 
the activating effect of $p$-cresol on cresolase activity of MT. ${ }^{48}$ Therefore, from an allosteric point of view, it is the structural features of the substrate which confer with the MT and reverse the metal ions effects. However, it is too soon to draw any border between these two explanations.

Acknowledgments. The financial supports provided by Research Council of University of Tehran and the Iran National Science Foundation (INSF) are gratefully acknowledged.

\section{References}

1. Mason, H. S. Advan. Enzymol. 1957, 19, 79.

2. Yasunobu, K. T. Mode of Action of Tyrosinase Pigment in Cell Biology; Gordon, M. Ed.; Academic Press: NewYork, 1959.

3. Raper, H. S. Physiol. Rev. 1928, 8, 245.

4. Martinez, M. V.; Whtaker, J. R. Trends Food Sci. Technol. 1995, 6, 195 .

5. Ahmad, F. Biochem. Biophys. Acta 1996, 1294, 63.

6. Handbook of Metal-ligand Interactions in Biological Fluids; Berthon, G., Ed.; Marcel Dekker: New York, 1995; Vol. 1.

7. Suresh, K.; Subramanyam, C. J. Inorg. Biochem. 1998, 69, 209.

8. White, L. P. Nature 1958, 182, 1427.

9. Sarna, T.; Korytowski, W.; Pasenkiewicz-Gierula, M.; Godowska, E. In Pigment Cell; Seiji, M., Ed.; University of Tokyo Press: Tokyo, 1981.

10. Palumbo, A.; d'Ischia, M.; Misuraca, G.; Prota, G.; Schultz, T. M. Biochim. Biophys. Acta 1998, 964, 193.

11. Palumbo, A.; d'Ischia, M.; Misuraca, G.; Prota, G. Biochim. Biophys. Acta 1987, 925, 203.

12. Flesch, P. Proc. Soc. Exp. Biol. Med. 1949, 70, 79

13. Bowness, J. M.; Morton, R. A. Biochem. J. 1953, 53, 620.

14. Bowness, J. M.; Morton, R. A.; Shakir, M. H.; Stubbs, A. L. Biochem. J. 1952, 51, 521.

15. Dorea, J. G.; Pereira, S. E. J. Nut. 1983, 113, 2375.

16. Molokhia, M. M.; Portnoy, B. Br. J. Dermatol. 1973, 88, 347.

17. Horcicko, J.; Borovansky, J.; Duchon, J.; Prochazkova, B. HoppeSeyler's Z. Physiol. Chem. 1983, 354, 203.

18. Seo, S. Y.; Sharma, V. K.; Sharma, N. J. Agric. Food Chem. 2003, $51,2837$.

19. Van Gelder, C. W. G; Flurkey, W. H.; Wichers, H. J. Phytochemistry 1997, 45, 1309.

20. Gheibi, N.; Saboury, A. A.; Haghbeen, K.; Moosavi-Movahedi, A. A. Colloids and Surfaces B: Biointerfaces 2005, 45, 104.

21. Karbassi, F.; Haghbeen, K.; Saboury, A. A.; Rezaei-Tavirani, M.; Ranjbar, B. Biologia 2004, 59, 319.
22. Karbassi, F.; Haghbeen, K.; Saboury, A. A.; Ranjbar, B.; Moosavi-Movahed, A. A. Colloids and Surfaces B: Biointerfaces 2003, 32, 137

23. Linder, M. C. In Biochemistry of Copper; Plenum: New York, 1991.

24. Lee, Y.; Won, H.; Lee, M.; Lee, B. FEBS Letters 2002, 522, 135.

25. Takahashi, K.; Akaishi, E.; Yumiko, A.; Ishikawa, R.; Tanaka, S.; Hosaka, K.; Kubohara, Y. Biochem. Biophys. Res. Comm. 2003, 307,64 .

26. Li, S.; Nakagawa, A.; Tsukihara, T. Biochem. Biophys. Res. Comm. 2003, 324, 529.

27. Buzadzic, B.; Korac, B.; Lazic, T.; Obradovic, D. Food Res. Inter. 2002, 35, 217

28. Palumbo, A.; Misuraca, G.; D'Ischia, M.; Prota, G. Biochem. J. 1985, 228, 647 .

29. Haghbeen, K.; Tan, E. W. J. Org. Chem. 1998, 63, 4503.

30. Gheibi, N.; Saboury, A. A.; Mansuri-Torshizi, H.; Haghbeen, K.; Moosavi-Movahedi, A. A. J. Enz. Inh. Medi. Chem. 2005, 20, 393.

31. Haghbeen, K.; Tan, E. W. Anal. Biochem. 2003, 312, 23.

32. Strothkamp, K. J.; Jolley, R. L.; Mason, H. S. Biochem. Biophys. Res. Commun. 1976, 70, 519.

33. Kelly, S. M.; Price, N. C. Biochem. Biophys. Acta 1997, 1338, 161.

34. Pace, C. N. Crit. Rev. Biochem. 1975, 3, 1.

35. Pace, C. N. Methods Enzymol. 1986, 13, 266.

36. Pace, C. N. Trends Biotechnol. 1990, 8, 93

37. Ahmad, F. J. Iran Chem. Soc. 2004, 1, 99.

38. Cicero, R.; Gallone, A.; Maida, I.; Pintucci, G. Comp. Biochem. Physiol. 1990, 96, 393

39. Young, G.; Leone, C.; Strothkamp, K. G. Biochemistry 1990, 29 , 9684.

40. Rodionova, N. A.; Semisotnov, G. V.; Kutyshenko, V. P.; Uversky, V. N.; Bolotina, I. A. Mol. Biol. (Mosc) 1989, 23, 683.

41. Semisotnov, G. V.; Rodionova, N. A.; Razgulyaev, O. I.; Uversky, V. N.; Gripas, A. F.; Gilmanshin, R. I. Biopolymers 1991, 31, 119.

42. Fink, A. L. In The Encyclopedia of Molecular Biology; Creighton, T. E., Ed.; John Wiley \& Sons, Inc.: New York, 1999.

43. Uversky, V. N.; Li, J.; Fink, A. L. J. Biol. Chem. 2001, 276, 10737.

44. Pifferi, P. G.; Baldassari, L.; Cultera, R. J. Sci. Food Agric. 1974, 25, 263.

45. Janovitz-Klapp, A.; Richard, F.; Goupy, P.; Nicolas, J. J. Agric. Food Chem. 1990, 38, 926.

46. Janovitz-Klapp, A.; Richard, F.; Nicolas, J. Phytochemistry 1989, 28, 2903.

47. Nardini, M.; Natella, F.; Gentili, V.; DiFelice, M.; Scaccini, C. Arch. Biochem. Biophys. 1997, 342, 157.

48. Shareefi-Borojerdi, S.; Haghbeen, K.; Karkhane, A. A.; Fazli, M.; Saboury, A. A. Biochem. Biophys. Res. Comm. 2004, 314, 925. 